\title{
Don't Fence Me In: Barricade Sociality and Political Struggles in Mexico and Latvia
}

\author{
DACE DZENOVSKA
}

University of Latvia

IVÁN ARENAS

University of Illinois at Chicago

\section{THE REVOLUTIONARY MOMENT}

Throughout the first months of 2011, Tahrir Square in Cairo vibrated with what seemed like the new collective consciousness of a revolutionary movement sweeping the Middle East. Collectively dubbed the "Arab Spring," the protests that erupted in Algeria, Lebanon, Jordan, Oman, Egypt, Syria, Yemen, Bahrain, and Libya following Tunisians' successful overthrow of their president have produced impassioned debates from commentators about how these revolutionary sentiments emerged and what possibilities, as well as risks, they entail. Assessing Egypt's future after the overthrow of Hosni Mubarak's regime, many liberals in the West have questioned whether Egypt will implement a liberal democracy or whether a totalitarian and religious state will emerge from the ashes of Mubarak's government. In turn, anthropologists such as Talal Asad have cautioned against conceiving of Egypt's political future in terms of a juxtaposition of religion and secularism, noting instead that

\footnotetext{
Acknowledgments: We express our gratitude to the editors of Laboratorium: The Russian Social Sciences Review, and to the editors of their special issue on the former Soviet Union and Latin America, for the initial invitation to consider Mexico and Latvia in a comparative perspective. The first part of that project was published in Laboratorium in 2010. We also thank Alexandre Beliaev, Brad Erickson, Charles Hale, Cindy Huang, Katherine Lemons, Tomas Matza, Rafael Sanchez, Alexei Yurchak, and the anonymous CSSH reviewers for stimulating questions and comments on earlier versions of the paper. Research funding was provided by Wenner-Gren Foundation and University of California-Mexico (UC-Mexus) grants. All translations from Latvian and Spanish are our own.
}

Corresponding author: Dace Dzenovska (dace.dzenovska@gmail.com). 
people in Egypt are talking about a "civil state," even as its contours remain unclear (in Schneider 2011). ${ }^{1}$

Whether hesitant or confident of lasting change, many commentators assessing the future of the Arab Spring fold the revolutionary moment into a teleological narrative leading from oppression to liberation. In such a narrative, Tahrir Square is part of a longer process that could succeed or that could be betrayed. ${ }^{2}$ However, we suggest that folding Tahrir Square into a teleological narrative of Egyptian liberation overlooks the ways in which practices of protest - such as building barricades around Tahrir Square-helped make the Egyptian revolution and were not simply revolutionary techniques deployed for a pre-formulated purpose. ${ }^{3}$ Indeed, as Talal Asad has recently suggested in relation to the Egyptian revolution, "In some cases, people discover that they've got some power they didn't think they had-even a technique they did not intentionally develop, but which they suddenly find themselves with and begin to understand. Maybe one needs to think of the uprising as more than a technique for getting rid of a despotic regime, but as a mode of existence, almost" (in Schneider 2011). This "mode of existence," we suggest, was both a condition of possibility for revolutionary practice, as well as its effect. While shaped by historical sedimentations, including other moments of disquiet, protest, and organizing (Hirschkind 2011a), it was nevertheless precisely the "mode of existence" of the uprising itself that articulated the revolutionary subject - the people-whose voice was heard rising up from Tahrir Square (Hirschkind 2011b; Wright 2011).

From Hegemony and Socialist Strategy (1985, with Chantal Mouffe) to On Populist Reason (2007), Ernesto Laclau has engaged precisely this question: how does the unified voice of the people emerge in a political arena characterized by difference? Laclau's sustained line of argumentation offers a compelling claim that the people do not exist as an a priori formation but are articulated through political practice. We find, though, that Laclau's analysis rhetoricizes the political and does not consider the political force of concrete material practices of protest and the ways they contribute to the articulation of the collective subject of the people. ${ }^{4}$ Informed by the work of Louis

1 See Nathan Schneider's (2011) interview with Talal Asad. Critical of the state as a modern political form, Asad notes that it is not that important whether the emerging political formation is secular or religious, because it is still a state. See also the recordings of a discussion at the University of Berkeley in May 2011, in which faculty and students critically engage predominant renderings of the Arab Spring in the Western public and political arena (Doumani 2011).

2 See, for example, Jumanah Younis' (2011) article in the Guardian where she suggests that Egypt's revolution will mean nothing if Egypt's women are not liberated from the "deep-seated misogyny" prevailing in Egypt.

See Mark Traugott's The Insurgent Barricade (2010) for a recent detailed historical analysis of the barricade not only as a defensive material construction but also as a revolutionary technique capable of recruiting revolutionaries out of bystanders.

${ }^{4}$ We thank an anonymous CSSH reviewer for urging us to engage with this point more explicitly. 
Althusser (1970) and Henri Lefebvre (1995 [1974]) on the relationship between materiality and subjectivity (see also Buchli 2002; Miller 2005), in this paper we argue that it is crucial to trace the specificity of the constitution of the people in different historical moments and to consider the importance of material practices to the discursive formations through which the collective political subject of the people is constituted. We lay out this argument in the first two sections of the paper through an analysis of the practices of making, maintaining, and remembering barricades in two revolutionary moments and their aftermath: in Riga, Latvia in 1991, where the tauta - understood as a unified and undifferentiated people — stood against Soviet military units attempting to prevent the dissolution of the USSR, and in Oaxaca, Mexico in 2006, where the populist collective of el pueblo (the people) sought to remove governor Ulises Ruiz Ortiz after the failed repression of a teachers' strike. We analyze Latvia's barricade events through the narratives of participants, via the commemoration of the barricades in contemporary narratives of state-building, as well as through the recollection of barricade events in contemporary political struggles over the public visibility of gays and lesbians in Latvia. We analyze Oaxaca's barricades via the narratives of participants and through the importance of the barricades to continued social and political struggles as manifested in Oaxacan street art.

In both contexts, we show that the building and maintaining of barricades produced an affective and visceral togetherness - or a barricade sociality - that articulated the collective political subject of the people. That is, the pragmatic practices of building barriers, guarding streets, procuring food, or huddling together generated social relations that turned strangers into comrades and conjured up the revolutionary people. Furthermore, we argue that this revolutionary subject position is not separable from the material practices of the barricades. That is, the collective subject of the people cannot be fully captured by sociological criteria such as ethnicity or class, or reduced to previous or subsequent populist articulations, even as such articulations do shape the specific contours of the people as produced by barricade sociality. For example, the barricade events in Mexico and Latvia took place within broader social movements headed by the Asamblea Popular de los Pueblos de Oaxaca (APPO) in Mexico and the Popular Front in Latvia. Yet these movements continuously struggled with how to articulate unity out of difference, whether of demands or identification. Emerging in especially consequential moments of the struggle, the barricades managed to create unity primarily through pragmatic practice rather than political rhetoric. As we show, this unity was a surprise to barricade participants themselves. It is precisely this dynamic of how collective subjects are constituted through material practice that we want to emphasize by carving out the barricades as an especially noteworthy and generative moment in these broader social movements.

In addition to tracing the constitution of the revolutionary subject of the people through barricade building, we examine the political potential that 


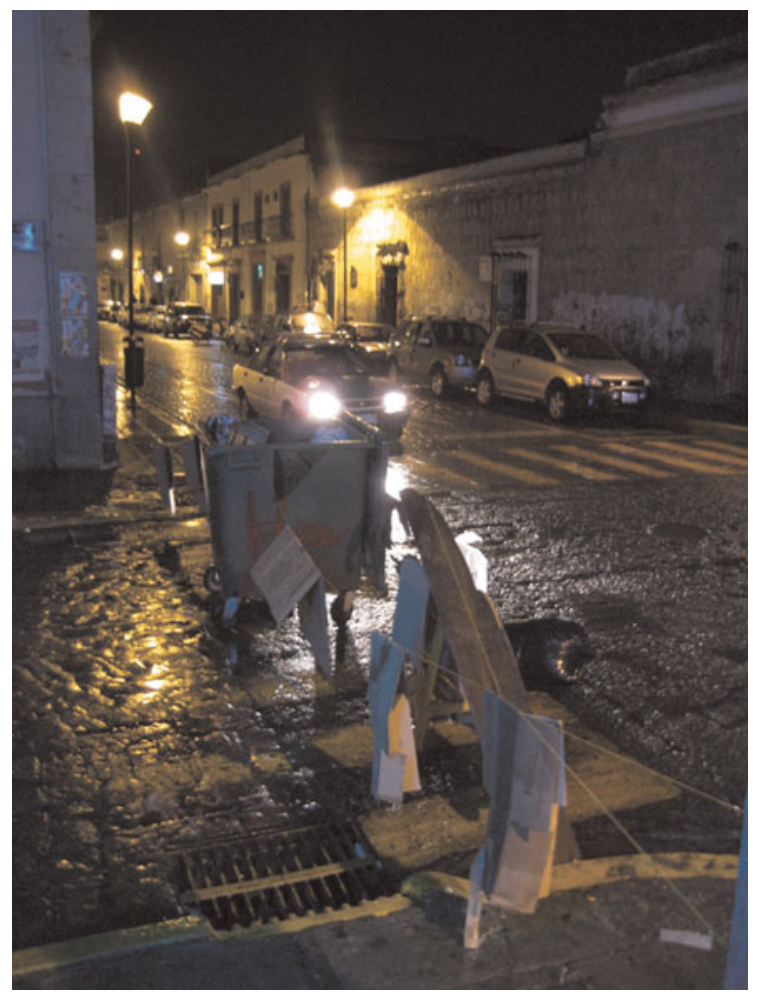

FIgURE 1 A barricaded street in Oaxaca, 2008. Photo by Iván Arenas.

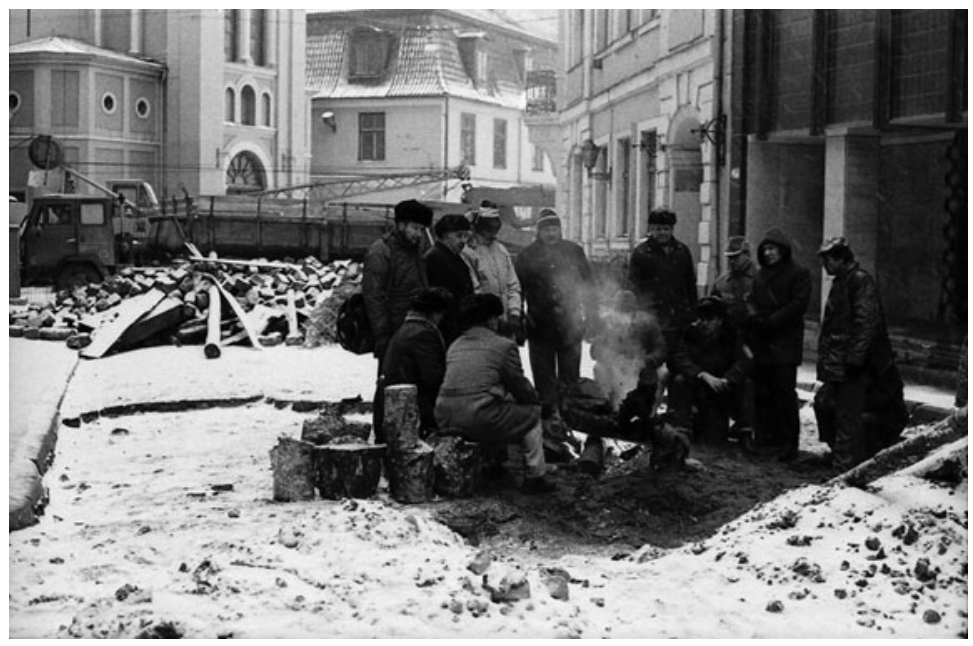

FIGURE 2 A barricaded street in Riga, 1991. Photo by Ilgvars Gradovskis. Courtesy of the Latvian Museum of the Barricades. 
this collective subject engendered in Oaxaca and in Riga. Though organized in relation to antagonisms with the ruling regime, we argue that the transformative potential of the people as produced by barricade sociality extended beyond its antagonistic relation to a particular state in Latvia or a particular political regime in Oaxaca to encompass a broader critique of modern political forms and practices of governing. In making this argument, we draw on critical scholarship of the modern state and of modern political forms and practices, such as that of Michel Foucault (2003), Ian Hacking (2007), and Michael Warner (2005). Concurring with Timothy Mitchell's (1991) argument that "the state" is constituted through the effect of taking the myriad practices of governing to be an institution that stands apart from the performance of these very practices, we argue that barricade sociality in Oaxaca and Riga unsettled the mirage of the state and offered glimpses of alternative possibilities for organizing collective life. Namely, barricade practices produced what participants in both Oaxaca and Riga refer to as an unprecedented solidarity which disrupted modern practices of governing that manage the population through difference, for example through differences between ethnic groups or between socioeconomic classes.

In the third section, we trace the legacies of the transformative political potential of the barricades in post-barricade politics. While the transformative political potential of Latvia's barricade sociality is alive in contemporary Latvian political imaginations, this potential cannot materialize because revolutionary politics has turned into the politics of the state and the people articulated together by the barricades have become its divided polity. In Mexico, due to historical differences, as well as greater disillusionment with the governing regime, post-barricade political imaginaries continue to generate alternative political futures even as the possibility of transforming Oaxaca's political order has lessened after the barricades. Thus, a comparative analysis of the barricades and their aftermath enables us to consider how the revolutionary subjects of el pueblo and the tauta that emerged in Oaxaca and in Riga during the barricades converge in a critique of modern political forms and practices of governing even as the historical conditions and contemporary power relations that characterized each site and situation lead to divergent post-barricade politics.

We consider our analysis of these revolutionary moments and their aftermath in Mexico and in Latvia as good to think with when asking questions about contemporary events in Egypt and elsewhere in the Middle East. We suggest that careful attention to revolutionary and post-revolutionary practices on the ground might produce different understandings of the political struggles in the Middle East than those which fold the Arab Spring into the discursive terrain of freedom, democracy, and the capitalist market. In our conclusion, we note resonances between Egypt, Mexico, and Latvia as sites positioned by Western commentators as "not quite there" on a global scale in relation to such formations as the free-market economy, political liberalism, and 
representative democracy. Rather than ask how social movements have contributed to filling in these gaps or romanticize the people as an enabling, utopian political formation, we end by calling for greater attention to how practices of protest in Cairo, Oaxaca, and Riga produce political subjects and social transformations that offer an important critique of state-based politics of liberation.

\section{BUILDING BARRICADES AND MAKING THE NATION IN LATVIA}

"This morning I have a barricade feeling," said Aina as she stood inside a mesh fence enclosure surrounded by a police cordon, waiting for the beginning of the third gay and lesbian Pride parade in Riga. That July morning in 2007, Aina invoked the Riga barricades of 1991 to mark what she saw as the profound political and existential consequentiality of the Pride parade that made her attend despite the atmosphere of fear and uncertainty surrounding it. If, in 1991, people stood up against the Soviet military units preparing an assault to prevent the dissolution of the USSR, in 2007, people inside the mesh fence faced the protestors gathered to verbally and physically assault the participants of the Pride parade. In 2006, after citing a "threat of violence," the Riga City Council had banned the Pride parade. Though a parade through Riga's streets did not happen, the events that did take place were subject to serious verbal and physical assault. Among the most visible protestors in both 2006 and 2007 were men and women from radical political organizations and religious communities, as well as from emerging "family defense" networks. Despite the unlikely alliance between evangelical Russians and Latvian nationalists, protestors shared a claim to speak in the name of the tauta-here articulated as a moral majority - and demanded that minority rights for public assembly not be placed over and above the majority's wish and the Constitutional imperative to maintain a virtuous public space. ${ }^{5}$

Aina was not the only one to draw parallels with the barricades to narrate the political and existential consequentiality of the Pride events. For example, another participant of the 2006 Pride events described his experience via a comparison and invocation of sensory memory of the demonstrations that took place during the Latvian independence struggles of the late 1980s:

The feelings I had that Saturday reminded me of the 1989 demonstrations in Riga when the People's Front ${ }^{6}$ had invited people to peaceful protests against the Soviet forces. People's minds and bodies vibrated from the tension; nobody knew what was going to happen-will Soviet soldiers surround us, will the tanks come, the special police

\footnotetext{
5 The Constitution of the Republic of Latvia stipulates that the right to assembly can be limited "in order to protect the rights of other people, the democratic state apparatus, the safety, well-being and virtue of society" (Gobiņš 2006). Many protestors invoked this clause to argue that police should not provide protection to Pride participants.

${ }^{6}$ The People's Front was a moderate political organization, and later political party, that played a central role in independence struggles and in forming the independent Latvian state.
} 


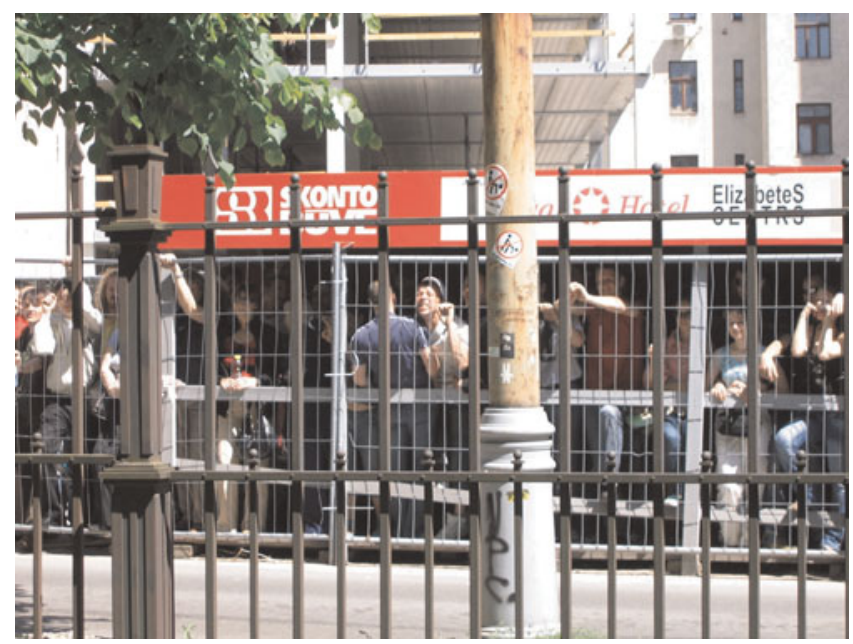

Figure 3 Fences Surrounding Pride in Riga, 2007. Photo by Dace Dzenovska.

forces, or KGB agents? Helicopters were flying above our heads on the riverside. In the Dome Square, people were quietly handing out small red-white-red flags; suspiciouslooking men were taking photographs. On 22 July 2006 in Riga I felt similar to how I felt during the times of the People's Front. How many years did we have to live in a free and democratic state to come to the conclusion that this society is very far from truly understanding democracy? ${ }^{7}$

As a result of the violent protests of 2006, in 2007 the Pride parade took place in an enclosed park with access controlled by Pride organizers and police officers in combat gear, rendering attendance a loud political statement. Indeed, some potential participants did not attend, for they did not want to pass the crowd of roaring protestors and enter the fenced enclosure through police checkpoints. A good number of those who attended felt apprehensive and, though they felt it important that they be there, some expressed relief that soon the anxiously anticipated event would be "done and over with."

Although, as indicated by references to the barricades, the sense of consequentiality people felt during Pride events in 2006 and 2007 was viscerally similar to that of independence struggles, the confrontations that generated it were also starkly different. During the barricades in 1991, the confrontation occurred between the tauta - that is, the people - as a united, inclusive, and liberating force and Soviet military units, which in that moment represented an imposed and oppressive totalitarian state. As recalled by one barricade participant, "We all had a common enemy. We did not have anything to fight over. And the enemy was not the Russians. The Russians were also on the

\footnotetext{
7 From www.mozaika.lv.
} 
barricades.... Our enemy was the system which made us all into slaves" (Kazans 2008). In 2006 and 2007, in turn, the sense of political consequentiality and uncertainty felt by Pride participants resulted from the threat of a confrontation between differentiated groups that were carved out of the revolutionary tauta. In 2006 and 2007, the confrontation was framed as one between a minority group and the political and moral majority now understood to be the tauta.

In invoking the barricades and independence struggles, Pride participants were not only conveying a parallel sense of consequentiality, uncertainty, and fear, but also summoning a past sense of future possibilities that they thought had not materialized in the years of Latvian state-building that followed the barricades. Many considered the fracturing of the united liberating force of the revolutionary tauta that manifested itself during the confrontations over Pride as the most unfortunate effect of post-barricade politics. In 2007, Rita Ruduša, then-editor of the online policy portal "Politika.lv," explained in a newspaper interview: "We all stood there together on the Riverbank [in 1991] and said-for your and our freedom. It seemed that people really believed this slogan of the Awakening, which was a simple sentence. But suddenly, 15 years later, it turns out that this simple sentence has all sorts of supplements. For your and our freedom, but only if you are just like us" (in Nagle 2007). ${ }^{8}$ Today, it is often recalled - and not only in the context of gay and lesbian politics - that during the cold January days of 1991, people of all walks of life came together to construct barricades in the streets of Riga. In response to a radio address by Dainis İvāns, leader of the Popular Front, people from all corners of Latvia, including workers of Soviet collective farms and industrial complexes, made their way to the capital and used the Soviet state's heavy machinery to bring materials and build barricades. The barricades enclosed strategic sites such as the radio and television stations and key government buildings in the Old City that were deemed important for fending off the Soviet military units' attempt to prevent the dissolution of the USSR. Reports of the barricades produced shortly thereafter, as well as in retrospect, all emphasize the unprecedented solidarity that characterized the moment: "That's why we won. Everybody was on the barricades - stocky country tractorists, rangers who had been through the war in Afghanistan, karate and bobsled champions, punks and metallists, the disabled and convicted criminals, university professors, joint-venture accountants, kindergarten teachers and hard currency prostitutes, actors with swords and former legionaries" (Daugmalis 2001b: 15).

\footnotetext{
${ }^{8}$ The independence struggles of the late 1980s are known as the Third Awakening. The First Awakening refers to the nation-building efforts of young Latvian intellectuals during the second half of the nineteenth century. The Second Awakening marks the period following the 1905 Revolution up to World War I and the establishment of the first independent Latvian state. The Riverbank referred to by Rita Ruduša is a large thoroughfare that runs along the bank of the River Daugava that divides Riga into two parts. It was used by the Soviet government for military parades and also by the independence movement for popular demonstrations.
} 
Gathered together at the barricades, people joked, sang, and danced, all the while retaining the awareness that any minute they may have to take defensive positions on the barricades to mount non-violent resistance to Soviet military units. A book dedicated to the barricade days issued just months after the 1991 events conveyed the unity of the people of the barricades, especially emphasizing the togetherness of Latvians and Russians, with a language and sense of immediacy not yet layered over by years of official commemorative events and state-building:

Today [in 1991] Latvians are a minority in Riga, only 36.5 percent from the total number of Rigans. However, the days of the barricades attested that in Latvia one people do not stand against another, but rather that supporters of the future and democracy stand against the forces of empire and totalitarianism.... During those days, Riga lived in other, irrational dimensions.... There was something cosmic in the air-the cold winter sky, silhouettes around bonfires, wood, trucks, singing of men's choirs, folklore of the barricades, political cartoons on the wooden walls - all merged in unity, and that was Riga (Daugmalis 2001a).

In terms of political history, Riga's barricades paved the way for the formation of the post-Soviet Latvian state. Ernesto Laclau notes that the creation of an internal frontier dividing society into antagonistic camps is crucial to the creation of the people (2007: 74). A reconfiguration of the internal frontier of society from a division between Latvians and Russians to a division between the people and Soviet military units was crucial to the formation of the tauta, thus seemingly confirming Laclau's theory that populist articulations require the existence of a frontier separating the people from its enemy. The material practices of building and maintaining the barricades in Riga, though, produced a barricade sociality that did not depend on the existence of a frontier alone, but was also, and most importantly, constituted through the pragmatic practices of keeping each other warm, nourished, awake, and cheerful. Barricade sociality was created through common material practices, rather than merely through the rhetorical construction of a common enemy, and was integral in rendering the tauta as a "cosmic force" - a revolutionary subject whose unity surprised not only Soviet military units, but also barricade participants themselves.

Prior to barricade building, for example, many Latvians looked at Latvia's Russian-speaking residents with distrust (Bicēna 2010; Daugmalis 2001a). During the most recent episode of the centuries-long colonial and socialist entanglements between Latvians and Russians, the Soviet nationalities policy had produced Latvians and Russian-speakers as two distinct publics with diverging understandings of history and politics. ${ }^{9}$ For many Latvians, Russians were

\footnotetext{
9 The Soviet nationalities policy did not treat Russians as a specific ethnic group, but rather cultivated Russian-speakers of different ethnic origins as the Soviet people in the making. Thus, while Latvians were ethnic, Russian-speakers were thought to have transcended ethnic identification. In the post-Soviet period, the Latvian state took great care to separate out ethnic groups from the indistinct mass of Russian-speakers (Dzenovska 2009; Slezkine 1994).
} 


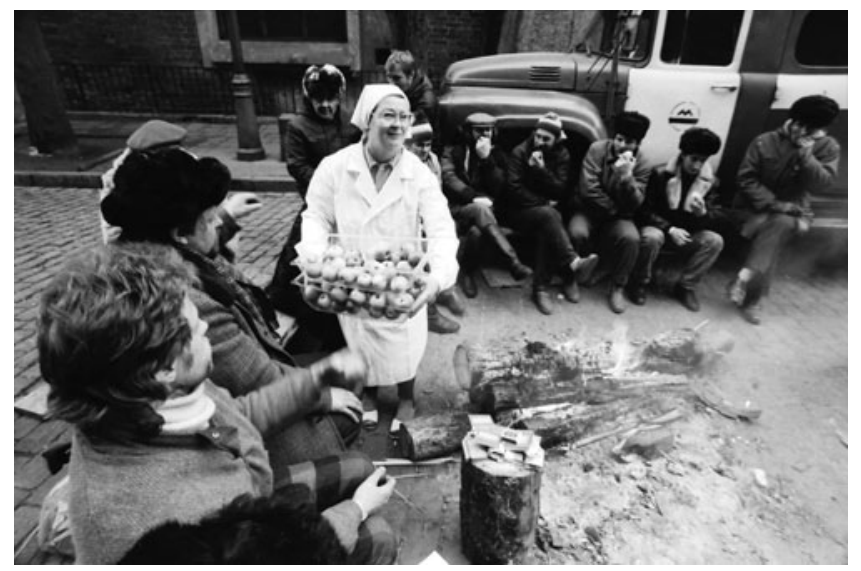

FiguRE 4 Barricade sociality in Riga, 1991. Photo by Ilgvars Gradovskis. Courtesy of the Latvian Museum of the Barricades.

distrusted agents of the russifying Soviet state rather than fellow citizens struggling for freedom and democracy, while for many Russian-speakers living in the Soviet Socialist Republic of Latvia, Latvians were reactionary nationalist elements. The barricades disrupted, if momentarily, this internal frontier produced partly by Soviet governing practices and partly by the political imaginaries of the national independence movement. This was not an absolute disruption insofar as some Russian-speakers, but also some Latvians, had joined the International Front—a political organization consisting of supporters

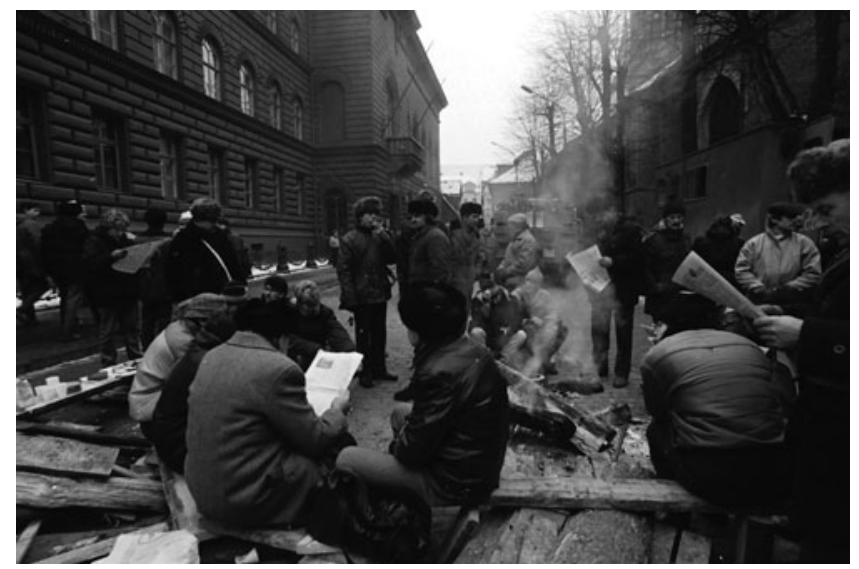

FIgURE 5 Barricade sociality in Riga, 1991. Photo by Ilgvars Gradovskis. Courtesy of the Latvian Museum of the Barricades. 
of the Soviet state and countering the activities of the Popular Front. The important point here, however, is that the frontier between the Popular Front and the International Front did not map onto ethnic divisions, though the expectation was that it would.

In the face of cold, darkness, and potential violence, folks at the barricades forged solidarities by sharing clothing, food, and drink, by singing, dancing, and playing music, and by setting up field clinics and providing medical aid, as well as by circulating information about political developments and military tactics. Many barricade participants recall how Russianspeaking employees of the Soviet milicia (police units) surprised everyone by siding with the people of the barricades rather than the Soviet military units, as well as how Russian women brought food to those who maintained the barricades. Barricade participant Guntars Laudums, for example, described how two elderly Russian women emphasized that the food they brought was not poisoned, demonstrating an awareness of how their gesture might have been perceived as suspicious given prevailing political and social divisions (in Daugmalis 2001a: 91).

Retroactive discourses highlighting the togetherness of barricade sociality form an important part of Latvia's contemporary social and political imaginary; yet, they often overlook the fact that barricade-building practices were not only structured by the emergence of a democratic people struggling against a totalitarian state but were also animated by a political imaginary of a cultural nation struggling for independence against an oppressive force, sometimes conceived as a totalitarian state and sometimes as Russian imperial expansion. It was precisely this simultaneous articulation of two political subjectivities - one of the people as a revolutionary force struggling against a ruling regime and the other of the people as a cultural nation (or Volk) struggling against political and cultural domination - that shaped the specific material and spatial practices of the barricades in Latvia, as well as ensuing state-building practices and political imaginaries.

The understanding of the tauta as a cultural nation was forged during the late nineteenth century when Latvian struggles against German economic and Russian political domination were articulated as struggles of national self-determination. The initial claims of national activists emerging out of the peasantry, or Jaunlatvieši (New Latvians), as they were mockingly called by the Baltic German elites, were for cultural self-determination, and the activists themselves could not quite agree on whether such an aim required political independence or whether it could be achieved within the political structures of the Russian Empire (Dribins 1997). Latvian political independence, which materialized in 1918, was partly due to the historical conditions when, in the aftermath of crumbling empires, nation-states were forged in Eastern Europe under the supervision of the League of Nations (Cowan 2007; Weitz 2008). The rendering of the tauta as a Latvian cultural nation was further solidified 
during the first independence period from 1918 until Soviet occupation in 1940 through public and political discourse, state policies, as well as educational and cultural activities (Purs 2002). These historical legacies shaped the identification of the 1991 revolutionary subject of the tauta with the cultural nation.

Yet, the barricade sociality forged in the trenches also rendered the tauta as the people of the barricades, that is, as an inclusive, democratic, and solidaritybased revolutionary force that surpassed the boundaries of the cultural nation. In the revolutionary moment, the articulation of both the cultural and the democratic inflections of the tauta increased its foreseeable and imagined revolutionary potential. Many Russian-speakers who came to Latvia during the Soviet years felt in 1991 that it was precisely because they were struggling together with the Latvian cultural nation that they were part of the tauta as a democratic collective and a revolutionary force. The subsequent state-building practices of modern government undermined this sense of togetherness and political possibility through exclusionary citizenship laws and by divisive processes that governed and divided the population through such categories as the majority and minorities (Arendt 1979; Cowan 2007; Dzenovska n.d.). Fearing that loyalties of Soviet-era Russian-speaking incomers lay elsewhere, once political independence was achieved, Latvian politicians decided to restore the prewar body of citizenry (1918-1940) rather than grant Latvian citizenship to everyone living in Latvia in 1991, as was the case in 1918 when the first Latvian republic granted citizenship to everyone who resided in the territory of Latvia before 14 August $1914 .{ }^{10}$ The category of resident non-citizen was established in 1995 for those who could not confirm a descent-based relationship to the prewar Latvian state. Resident non-citizens could obtain citizenship through a naturalization process, which required swearing allegiance to the new state, as well as demonstrating basic knowledge of language and history. Many Russian-speakers who were on the barricades or who sympathized with the independence struggles were offended by such politics and chose not to naturalize. For many others, especially the elderly, the tests of language and history proved to be too difficult. As a result, about 290,660 of Latvia's current residents (out of 2.06 million) are still neither citizens of Latvia nor of any other state, though some are taking on the citizenship of Russia. ${ }^{11}$

We suggest, thus, that during the barricade-building moment in Latvia in 1991, there were two distinct senses - sometimes competing and sometimes complementary - of the transformative and revolutionary potential of the barricades; on one hand, there was a sense of this revolution as a restorative act

\footnotetext{
${ }^{10}$ See Stukuls Eglitis (2002) for a discussion of the divergent temporalities that characterized post-Soviet political discourses.

${ }^{11}$ See Silova (2006) and Arenas and Dzenovska (2010) for a more detailed discussion of this topic. The statistical data is taken from the latest population census in 2011. The data is available online from the Central Statistical Bureau: http://www.csb.gov.lv/statistikas-temas/2011gadatautas-skaitisana-galvenie-raditaji-33608.html.
} 
that would create a Latvian state on the basis of the pre-Soviet political and cultural entity; on the other, there was a sense of the revolutionary potential of the barricades to create an unprecedented unity and thus a hoped for total transformation. It is important to emphasize here that, as a revolutionary force generated by the barricades, the tauta cannot be measured or pinned down through sociological criteria. ${ }^{12}$ While concrete bodies and practices forged the barricade sociality which was formative of the revolutionary potential of the tauta in 1991, taken together, they do not amount to a particular demographic, social, or ethnic group, or any other entity that might be conjured up by the technologies used by modern states to study and govern their populations (Hacking 2007). Instead, taken together, these bodies form a revolutionary force that is best described as a potentiality or a vibration, to borrow from Gabriel Tarde's economic analysis (Lepinay 2007). ${ }^{13}$ The creation of the people as a cosmic revolutionary force offers a moment of possibilities, a source of changes, but "it escapes any measure in its purest form of potential" (ibid.: 526). In the aftermath of the barricades, as this revolutionary potential was institutionalized through modern practices of governing that divided the tauta into minorities and majorities, it was deprived of its revolutionary vibration. Thus, even as a recollection of the barricades in contemporary political struggles provides a sense of past solidarity as well as a sense of future possibilities against which contemporary public and political life is assessed, the revolutionary force of the people conjured up in these recollections is always-already circumscribed by the articulation of the notion of tauta as a cultural nation with practices of modern governing. In the case of Oaxaca, to which we now turn, building and manning the barricades likewise produced a barricade sociality that gave rise to the revolutionary subject of el pueblo (the people), yet its articulation with different historical trajectories also importantly affected its revolutionary vibration and the life of barricade sociality in the aftermath of the barricades.

BUILDING BARRICADES AND MAKING ELPUEBLO IN OAXACA

As had been the custom for over two decades, in May of 2006, Oaxaca's teachers union erected a tent-city in the zócalo (main plaza) of Oaxaca's historic World Heritage Site to hold an annual sit-in strike as a way to pressure the state

\footnotetext{
12 Something similar can arguably be said about the cultural nation as well, as no set of criteria fully captures its precise contours. The constitution of the cultural nation requires its performance as much as concrete bodies or abstract statistical entities. However, there were and are attempts to delineate the cultural nation on the basis of criteria such as ethnicity, citizenship, and so forth. The people as produced by barricade sociality challenge such criteria.

${ }^{13}$ In Vincent-Antonin Lepinay's interpretation, Gabriel Tarde argues that economic development occurs through moments of innovation-germs - rather than capital accumulation. While Tarde's analysis, as rendered by Lepinay, overlooks factors such as accumulation through dispossession to capital growth, it is useful here for how it describes innovative moments as pure vibrations whose potentiality escapes any measurement (Lepinay 2007).
} 
government for better working conditions. Typically resolved through negotiations, in the early morning hours of 14 June Governor Ulises Ruiz Ortiz sent in thousands of armed state police to break up the sit-in strike. Initially caught by surprise, teachers regrouped in the streets around the zócalo and, now joined by others who had heard of the police repression, physically retook the space. In the following days, the teachers' strike rapidly became a broader social movement including students, farm-workers, unions, multiple indigenous groups, and over three hundred left-leaning social and civic organizations. Estimated to include around a million people at its height, the Popular Assembly of the Peoples of Oaxaca, or APPO, as this assemblage came to be known, included an array of social actors ranging from dedicated anarchists and devout church groups to committed socialists all calling for the governor's resignation. ${ }^{14}$

Brought together through mutual antagonism to the governor, APPO's formation appears as a paradigmatic example of the process of articulation that Ernesto Laclau has identified as an integral condition of the political logic of populism (2007). In Laclau's assessment, the popular collective subject takes shape when plural demands are brought together and given expression by a central, unifying discourse that creates the internal frontier dividing a community into two antagonistic camps, the body who makes a claim and those to whom the demand is addressed (ibid.: 80-93). For the camp that comes to identify itself as the people, Laclau notes that, "the popular subject position does not simply express a unity of demands constituted outside and before itself, but is the decisive moment in establishing that unity" (ibid.: 99). Although articulated together through a shared discourse that repudiated the authoritarian political practices of Oaxaca's politicians, the unity and popular subject position of Oaxaca's social movement was likewise powerfully shaped by the practices of protest: from June 2006 to November of 2006, APPO members gathered thousands in popular assemblies and regularly held massive marches through Oaxaca's streets, took over local radio and television stations to broadcast their political messages, and physically occupied the historic city center. In late August of 2006, after paramilitary groups in moving vehicles shot and killed an APPO member, barricades were quickly erected across the city to protect against the government's "convoys of death."15

\footnotetext{
14 To organize this broad array of social actors, APPO turned to the indigenous governing practice of decision making through participatory assembly. This organizing model linked local assemblies in neighborhoods or colonies to statewide assemblies and to the APPO council, formed by 260 representatives from all seven regions of Oaxaca. However, with several hundreds of thousands actively participating, many significant actions - such as taking over the state television station or setting up barricades - were a response to the possibilities of the moment and people's mobilization rather than any strategic APPO plan or council decision.

${ }^{15}$ Gustavo Esteva describes "what people quickly called the 'convoy of death' [as]: thirty-six state government pick-ups with a thousand sicarios [mercenaries] dressed in black, shooting in the air" (2008: 25). State-sanctioned violence against Oaxaca's social movement included use of paramilitary
} 
Oaxaca's barricades were not simply a material expression of a populist APPO discourse opposing Ulises Ruiz Ortiz or the physical instantiation of a dividing line in space between differently positioned Oaxacan camps. Much as the practices of making and maintaining Latvia's barricades articulated together Russian-speakers and Latvians as the tauta, Oaxaca's barricades articulated a popular collective subject through the material and social practices entailed in their construction and maintenance. Yet, unlike Riga, where the barricades served to protect strategic sites and the possibility of political freedom for what was already being imagined as a nation-state, in Oaxaca, the sweaty work of carting old tires, wooden logs, broken cement, and sand-bags to create Oaxaca's barricades was largely the work of neighbors seeking to defend their streets from the threat of paramilitary forces but also from the threat of robbers in a city effectively without police.

Karl Marx's parable of the bee ${ }^{16}$ provides a model example of how modern reason privileges a perspective positing that the conceptual is of primary importance and that the material world of produced objects and spaces is merely the objective manifestation of reasoned thought. Critiquing this perspective, Henri Lefebvre reminded that, "like all social practice, spatial practice is lived directly before it is conceptualized; but the speculative primacy of the conceived over the lived causes practice to disappear along with life" (1995: 34; see also BuckMorss 2000). The triangulation Lefebvre posits between mental, material, and social spaces provides grounding by which to reconsider the assumption that practices such as barricade building are actions that merely reflect the reasoned intentions of those who carry them out and opens a consideration of how material practices of struggle affect—and not just reflect—revolutionary consciousness. Along similar lines, we find that Louis Althusser's essay on interpellation (1970) points to the importance of material practices and embodied habits to the production of subjects; while our focus on barricade building specifically addresses material practices outside of "Ideological State Apparatuses," we nonetheless find that Althusser's essay can be usefully read as a reminder that our beliefs, conceptions, and subjectivity are not only relational social constructs but are informed by material practices such as barricade building (see also Mahmood 2005; Žižek 2001). ${ }^{17}$

forces such as the convoy of death, sniper attacks on marchers, and extrajudicial kidnappings of APPO supporters. A human rights report estimated that "about twenty-six people have died, victims of the state government's deliberate violence towards manifestations" (Diakonie 2007: 27), and that "between five hundred and seven hundred people have been arbitrarily detained" (ibid: 31 ).

${ }^{16}$ As Marx put it: “.... bee puts to shame many an architect in the construction of her cells. But what distinguishes the worst architect from the best of bees is this, that the architect raises his structure in imagination before he erects it in reality. At the end of every labor process, we get a result that already existed in the imagination of the laborer at its commencement" (1990 [1867]: 456).

${ }^{17}$ Though often overlooked, Althusser focused the majority of his essay on interpellation not on the paradigmatic moment of a policeman hailing a subject on the street, but on the role of 
With estimates of over fifteen hundred barricades having been simultaneously set up across the city, the neighbors moving rubble out into the street, sharing food and coffee, building bonfires, and securing the lookout post so that others could sleep were united through material practices and by the opportunity these afforded to open dialogues; those on the barricades, though, were also acutely aware of their constitutive differences. As David Venegas, an APPO council member selected as a representative of the barricades stated: "In the barricades we were many fighting 'for a better society', but this society has many faces. A housewife sees an oppressive government that raises the price of services and does not provide healthcare for her kids. As a student I see more the deficiencies of education, the barriers set up for opportunities to develop. Many street kids want to 'thrash' the police. They have a legitimate reason for rebellion, yet a fuzzy conviction. It enriches us to understand them" (in Gijsbers 2007: 246). It was through the shared practice of building barricades - most of which were put up in the evening and taken down the next morning - that people across the city who may have lived next to each other all their lives but never spoken began to recognize each other as compañeros (comrades). Through the sweaty work and shared effort of building barricades, people were remaking both the city and their social relations - building not only material structures but also a common sociality.

Much as in Riga, an important part of the cosmic force of Oaxaca's social movement stemmed from how material practices created the emergent and viscerally lived sense of togetherness that we refer to as barricade sociality. With many neighbors on the barricades not forming part of APPO and voicing critical opinions of both Oaxaca's governor and APPO, and with incongruent groups forming part of APPO, competing claims and divergent horizons of expectation challenged the creation of a common discourse. Barricade sociality was therefore critical to the articulation of the populist collective subject of el pueblo (the people); many of the individuals and groups who came to identify themselves as part of Oaxaca's populist collective subject of el pueblo or the Latvian tauta were articulated together through the barricade sociality engendered by the shared practice of building and maintaining the barricades. Thus, rather than reflect a pre-established boundary produced by the recognition of a common claim, barricade building in both Oaxaca and Riga served as catalysts for new social formations and were integral to the creation of the shifting frontiers of el pueblo and the tauta.

\footnotetext{
Ideological State Apparatuses in inculcating the material practices that come to define expectations about the appropriate behavior and beliefs of particular subjects. Internalized and enacted by individuals, these are critical to the iconic moment of interpellation, which is a relational moment between someone who hails an individual as a particular subject and that individual recognizing themselves as that subject.
} 
As in Latvia, in Mexico too el pueblo has various historical iterations. It is thus useful to briefly trace this genealogy in order to highlight the distinctive nature of the various popular identifications of el pueblo, as well as to point to the social and political stakes of these identifications through barricade sociality in the present. To begin with, while "el pueblo" is often translated as or is assumed to be synonymous with "the people," the embodied and affective quality of el pueblo that Oaxaca's populist movement cultivated in 2006 has a specificity that cannot be captured by an abstract concept or by its translation as "the people" as generally imagined in state-based democracy. ${ }^{18}$ In Spanish, el pueblo has the dual connotation of referring both to a "people" and a "town." In Mexico, as Emilio Kourí notes, this articulation between people and place has its origins in colonial times when el pueblo was a juridical term placing the untamed, indigenous people and village at the lowest scale in a hierarchy from village to town to the white, civilized city (2002). An evolutionary logic locating brown Indians as savages and white Spanish settlers as civilized was central to how Spanish functionaries and the Spanish elite governed the Mexican colony, influencing the social and spatial relationship between people and place for centuries to come (Gay 2006 [1881]).

After gaining independence from Spain, the contrasting relationship between urban, white citizens and indigenous brown peasants became the centerpiece of subsequent state efforts to craft a governable Mexican nation. Under Oaxacan-born indigenous president Benito Juárez, for example, liberal governments in the mid-1800s attempted to introduce the category of citizenship as a way to transcend the social, spatial, and racial segregation of Mexico's indigenous population. However, as Claudio Lomnitz notes, "In the nineteenth century, the term Indian gained a new acceptance, fusing racial and class factors: for the urban middle and upper classes, any poor peasant was an "Indian"; that is, the category "Indian" came to mean those who were not complete citizens" (2001: 52). With the category of citizenship only furthering the gap between urban and rural identifications, Paul Eiss relates that during the long dictatorship of Oaxacan born president Porfirio Díaz (1876 to 1911) at the end of the century, "el pueblo became a strategy through which modernity and tradition were collaboratively produced by state officials and local elites" (2008: 525). Porfirian functionaries and Mexican elites poured money and praise onto urban projects materializing modernization while at the same time celebrating pueblo people and places for the lively color of their contrasting traditional customs.

18 The genealogy of the notion of "the people" in Mexico is different that in the United States or Europe. Western scholars tracing the rise of "the people" often turn to the American and French Revolutions as starting points, highlighting the transformation of hierarchical communal relations with God or King at the apex into communities of individuals whose equality manifested itself through rights and popular sovereignty (Arendt 1968; Taylor 2007). 
DON'T FENCE ME IN 66I

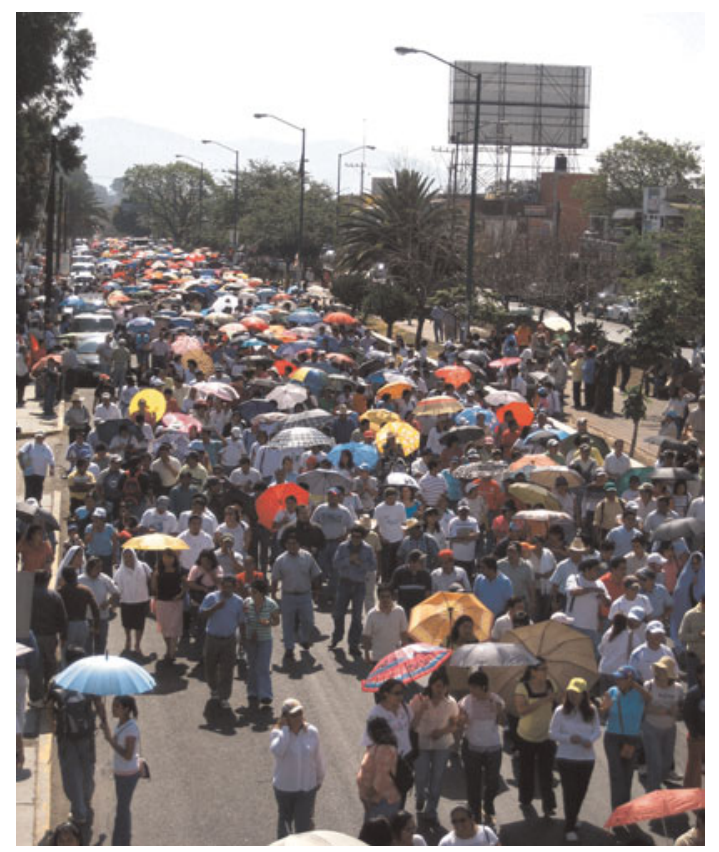

FIGURE 6 APPO Mega-march. Photo by Iván Arenas.

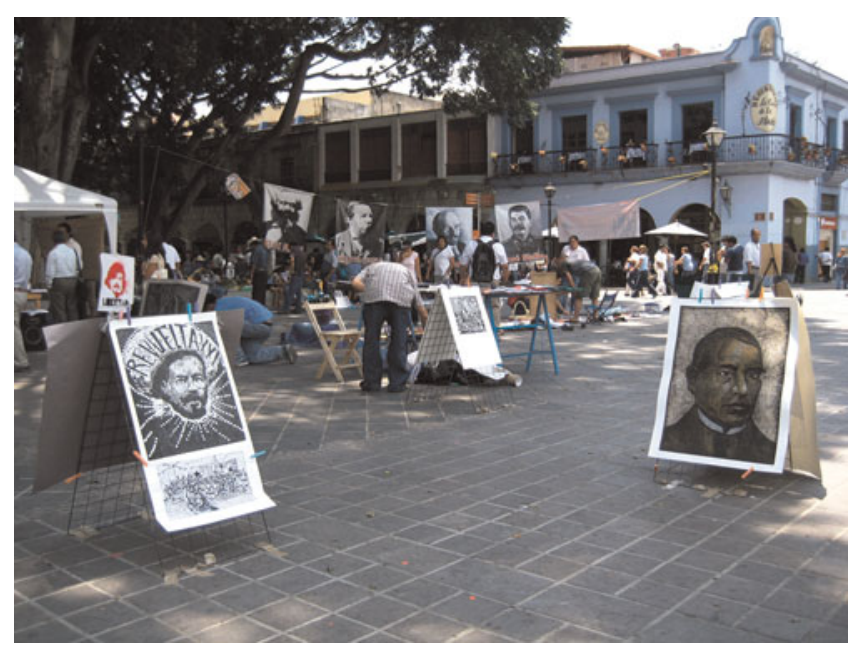

FIgURE 7 APPO take over of the zócalo in 2008. Here Mexican revolutionary Pancho Villa, indigenous President Benito Júarez, Karl Marx, Friedrich Engles, Vladimir Lenin, Joseph Stalin, and Oaxacans work to find common ground. Photo by Iván Arenas. 
At the start of the twentieth century, continued inequalities between el pueblo and elites were critical in fueling the Mexican revolution (19101917) and to the legitimacy of the newly formed political party of the Partido Institucional Revolucionario (PRI), who, in the name of uplifting el pueblo, instituted a patriarchal and authoritarian governing style that dominated Mexican politics at all levels from 1929 until recently. Florencia E. Mallon points out that, from the time of Mexican independence, it has been through armed struggle, liberal notions of citizenship, and the relational mappings of traditional indigenous and modern urban imaginations that the marginalized populations of el pueblo and the country's elites have negotiated the hegemony and contours of the Mexican state and nation (1995). Nonetheless, throughout the last five hundred years in Mexico, el pueblo has not generally been recognized as a political subject. ${ }^{19}$

If el pueblo suggests an incommensurable differentiation between the modern citizenship and political power of city and state elites and the traditional customs of insular, rural indigenous communities, Oaxaca's populist movement ruptured this identification in fundamental ways. For one, although many indigenous people with ties to pueblo villages participated, Oaxaca's social movement was largely and centrally an urban movement. Moreover, through the barricade sociality that developed from practices of struggle such as barricade building, the occupation of the historic city center, and massive public marches and assemblies, Oaxaca's populist movement brought together indigenous peasants and hard-core socialists, entrenched anarchists and middle-class intellectuals in a new articulation of what, who, and where the collective subject of el pueblo is. Rather than an ascribed identity, in Oaxaca in 2006, el pueblo was a collective subject constituted not through abstract notions of collective belonging but by concrete practices that construct shared social experiences and imaginaries. Through the take-over of the zócalo and through the neighborhood barricades in the streets, Oaxaca's populist movement not only reconstituted abstract public spaces into places of and for el pueblo, but also articulated together the collective subject of el pueblo as an insurgent social formation seeking rights to the city. ${ }^{20}$

19 During the 1920s and 1930s, for example, government projects turned to mestizaje-the fusion of traditional and modern elements, or indigenous and white races-as yet another avenue for the indigenous population to become Mexican national subjects. Whether through the state-sponsored iconography of Mexican muralist art, academic texts lauding the creation of a "cosmic race" (Vasconcelos 1997 [1925]), or celebrations of the archaeological past and traditional indigenous present (Gamio 2010 [1916]), celebrations of mestizaje offered a palliative cultural project that provided an updated image of el pueblo as the cultural embodiment of the soul of the nation; once again, governing regimes used indigenous culture to depoliticize el pueblo and the gap between elites and the marginalized majorities (see Poole 2004, for a critique of this dynamic in relation to Oaxaca).

${ }_{20}$ Although arguments about rights to the city often emphasize the articulation between public space and social and political inclusion (Harvey 1973; Mitchell 2003; Soja 2010), in Lefebvre's 
Though the Oaxacan pueblo has built new material and social relations that cut across the historically informed divisions of class, race, rural-urban, and ethnic differentiations, it is important not to romanticize these oftenlimited or small-scale engagements across difference; indeed, the repeated reiteration of these engagements and of the importance of barricade sociality in the aftermath of the barricades points at once to their transformative potential and also to the fact that such engagements were otherwise rare in Oaxacans' everyday life. The barricade sociality that was forged through the long and dangerous Oaxacan nights conjured up el pueblo as a united collective subject, despite their differences. In the process, the radical uncertainty that goes with any heightened moment of danger was transformed into a collective sense of possibility. As some have noted, barricade practices go a long way in explaining how mothers who would ordinarily have called the police upon seeing street kids with spray cans outside their doors now came out not only to encourage them but even to join them. Gustavo Esteva, an intellectual and long-time resident of Oaxaca, has written that social movements "are engines driven by experience, not by an imagined object or goal-although once the people are put in motion they find goals that correspond to their intention" (2007: 19). Still, emerging out of shared practices of struggle that put millions of Oaxacans in motion, the reconceptualization of the collective subject of el pueblo and the strong sense of its political and social possibility were certainly tenuous and fragile, and hence necessitated the continual reassertion of the subjective identity and identification of el pueblo. In a moment when the barricades, marches, and assemblies are largely a thing of the past, the next section addresses the continued importance of barricade sociality and of the identity and identification of the collective subject of el pueblo.

\section{FROM STREET TO STORY IN MEXICO AND LATVIA}

While the form of urban warfare practiced today is not as direct as that seen in the confrontations of 2006, from marches to songs to stencils, barricade sociality remains an important condition of possibility and groundwork for current struggles in Oaxaca. The clear-cut aesthetic and political message of Oaxacan political street art, for example, continues to carve out a space for the collective identification of el pueblo. Most often, though, images spraypainted or messages inscribed on the historic walls of Oaxaca do not put

coinage and development of the concept (2000 [1968]), making a space for politics does not mean simply fighting for inclusion of the marginalized in the visible spaces of the city, but rather making a space for conflict that questions the assumption of the normative ideal unity of the public, or of that unity as the goal or essence of the socio-political community (see also Lefebvre 1995; Rancière 2004; Watts 2004). 
forward particular demands against the state government in the name of $e l$ pueblo; rather, in the absence of practices of protest themselves, images on city walls interpellate el pueblo by way of the circulation and reiteration of images and statements referencing the barricades, assemblies, and marches of 2006 and articulating these as the collective work of el pueblo.

On a downtown Oaxacan wall in mid-2007, the Assembly of Revolutionary Artists of Oaxaca (ASARO) placed a stencil depicting a scene of Triqui marchers - the Triqui are one of Oaxaca's many indigenous groups and can be distinguished by the women's red garments. Written next to it, a statement read: "ASARO, arte del pueblo y para el pueblo" (ASARO, art of the people and for the people). Elsewhere in the city, another image depicted an archer with bow and arrow at the ready accompanied by the words "todo el poder al pueblo" (all the power to the people) and the APPO acronym written with an anarchist A and a peace sign for an O. On another wall, the words "nuestras armas" (our weapons) under a pair of shopping carts referenced the use of stolen shopping carts as transport for the paving stones and materials used to make the Molotov cocktails that defended the barricades in 2006. Instead of voicing a particular claim or an injunction to a specific action, these and other stencils hail el pueblo as a collective political subject in struggle. With images of Indian archers, mobilized indigenous communities, and others of Emiliano Zapata with a punk haircut or Benito Juárez with a beret sporting a red star, Oaxacan political stencils connect current and historical struggles of el pueblo, articulating the past and present in ways that suggest both continuity and change.

Yet, as both an artistic and a political practice, what kind of representation "of the people and for the people" is produced by placing such stencils on Oaxaca's city walls? In asking whether the subaltern can speak, literary critic Gayatri Spivak pointed out that in analyzing representations one must distinguish between "representation as 'speaking for' $\ldots$ and representation as 're-presentation"” (1988: 275). As is clear from ASARO's slogan and their images, while these political street artists feel they and their art speaks from the perspective of shared experiences as part of el pueblo, they do not claim to speak for el pueblo as its proxy representatives. Beyond a mere reflection of the common struggles and difficulties of el pueblo and an incitement to continue the struggle, what, then, is the function of these re-presentations? On the one hand, through their stark iconography and by the sheer fact that these images have been present in the streets and in Oaxacans' minds for some time, one effect of these re-presentations is that the collective subject of $e l$ pueblo that materialized through the struggles of 2006 has both come to identify with these images and to become identified by them. More importantly, the political function of these representations as both a public invitation for reflection and a call to continued action lies in their intervention in the hegemonic horizon of expectations that organize social life in Oaxaca, or what Jacques 


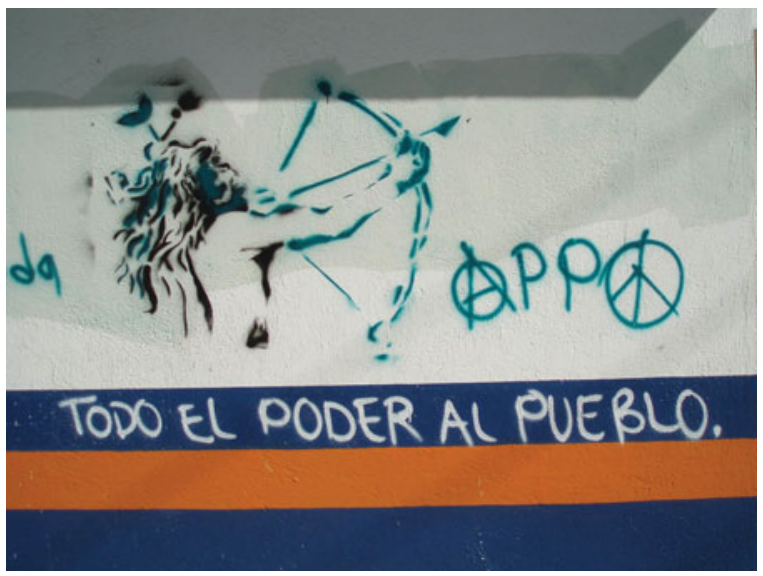

Figure 8 ASARO stencils, 2007. Photo reproduced with the permission of Itandehui Franco Ortiz.

Rancière calls "the distribution of the sensible" (2004). For Rancière, aesthetics has a political function insofar as it opens up or disrupts the bounded self and social community and exposes these as political and social constructions; in rendering visible the constructed nature of the grid of intelligibility that forms the social terrain organizing society, political street art puts into question this distribution of the sensible and opens up a space with possibilities for imagining, mapping, and acting out different political practices and political

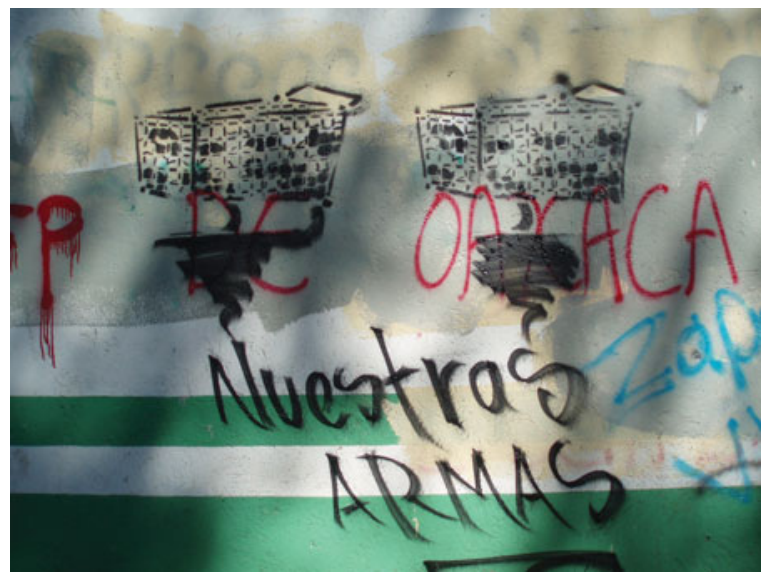

FiguRE 9 ASARO stencils, 2007. Photo reproduced with the permission of Itandehui Franco Ortiz. 
subjectivities. Referencing the struggles and political subjectivity of el pueblo, political street art in Oaxaca continues the labor of producing el pueblo and to situate its relevance in part in relation to the transformative social and political possibilities opened up by the emergence of barricade sociality in 2006 .

In repeatedly asserting the presence of the emergent subject of el pueblo in the material landscape, street art in Oaxaca interrupts the given distribution of the sensible of this city as a UNESCO World Heritage Site that is the patrimony of all oaxaqueños (Oaxacans) and of all humanity. In contradistinction to the ways in which, at its broadest, referencing el pueblo today marks out the collective subject position of all the individuals who were involved in struggles of the social movement of 2006 or who today would have affinities with it, oaxaqueño is meant to reference a more inclusive collective that would encompass everyone who lives in Oaxaca or who identifies themselves as Oaxacan. However, though official discourse returns to the question of the harm that is being done by street artists to the heritage of all oaxaqueños, street art-and police practices - illustrate the deep tension and contradictions between local struggles and universalizing discourses that mask and flatten multiple inequalities. In doing so, street art does "call into question the distribution of roles, territories, and languages" (Rancière 2004: 40) that position oaxaqueños and Oaxaca as a people and place largely in the service of a tourist economy from which elites and the government have profited handsomely but which has impoverished the vast majority and wrecked the social and material landscape in the process. ${ }^{21}$

With images continually situating el pueblo as a mobilized political subject - and as itself a political practice of protest - street art in Oaxaca also disrupts the contours of the normative "democratic patriarchy" (Mallon 1995: 75) that positions the PRI or other government functionaries as the patriarchal benefactors of a depoliticized and subjugated pueblo. Nonetheless, while subsequent reiterations of practices of struggle continue to inform the collective subject of el pueblo, as the material practice of building barricades has turned into an iconography, narrative, or debate about barricade sociality in the aftermath of the moment of building barricades, these reiterative references may hail el pueblo, but they fail to produce the revolutionary cosmic force and viscerally lived sense of togetherness of barricade sociality. While protest songs, stencils, marches, and barricades on significant dates continue to incite el pueblo to

\footnotetext{
${ }^{21}$ Under the pretext of modernizing the city for tourism, for example, Ulises Ruiz Ortiz undertook a series of urban transformations that included replacing the green stones for which the city is known for in the center with cement, wiping out a historic city block in order to build a first-class bus station, and amplifying a highway with such poor engineering that it caused a tremendous landslide that threatened the hillside community below. Though the state cited figures of \$US2.3 million spent in the zócalo in 2005, many put the cost at upwards of $\$ 60$ million and asserted that most of those funds went into the pockets of Roberto Madrazo, who was the PRI candidate in upcoming national elections (Arellanes 2007; Arenas 2011; de Aguinaga 2007; Martínez Vásquez 2007).
} 
action, these are in great part a struggle to create the conditions for barricade sociality in the present or work as a commemoration of the barricade sociality of the past. Similar to the ways that, for those surrounded by fences during Riga's Pride parade, barricade sociality provided a sense of past solidarity and a sense of future possibilities against which the present was assessed, in Oaxaca and Latvia, barricade sociality has become both a means by which to judge the present and an aspiration for hoped for transformations in the future.

Today, through books, films, coins, monuments, and in the Museum of the Barricades, Latvia's barricades have become part of the Latvian state's commemorative landscape. These commemorative practices not only posit the barricades as a glorious event on the road to Latvian political independence, but also invite further reflection on barricade sociality. Upon entering the Museum of the Barricades, visitors find themselves in a dimly lit room set up like a bonfire site. Visitors can sit on a cement block or a wooden log and listen to radio broadcasts from 1991 or watch amateur video footage of the events. In the corner of the room, there is a model of Riga's Old City slanted against the wall. It is filled with people huddled at bonfire sites that glow amidst barricade constructions. While the set-up of the room interpellates the visitor as a participant in the barricades, the model conjures up the sociality of togetherness by concretizing the imagination of what the barricade experience was like at the scale of the city. The exhibit creates a sense of the togetherness of the barricades and its political possibilities, yet it also reminds the visitor of the spectral presence of the state during the barricade days by folding the event into the political history of the Latvian state. For example, images of independence demonstrations of the late 1980s with people waving the Latvian flag are interspersed amidst the material on the barricades themselves. Although the populist collective subject of the tauta was articulated through the mobile dynamics of material relations of struggle and did not have a pre-existing revolutionary roadmap leading towards the Latvian state, this suggests that the "cosmic force" of the tauta is now viewed as a necessary stage in a teleological process leading from Soviet oppression to Latvian liberation.

Alongside the museum's recollection of the revolutionary potential of the tauta by recreating the physical and social space of the barricades, contemporary political discourses comment on the unity across difference that the barricades generated as a vanished political possibility in relation to contemporary political struggles. Thus, for example, gay and lesbian activists, as well as minority rights activists, critique divisions between citizens and non-citizens, or between sexual minorities and the majority through invocations of the barricade sociality of 1991. The obvious question that emerges out of such nostalgia for the lost possibilities is this: how did the revolutionary potential of the tauta get betrayed and by whom? How is it that fifteen years ago "we all stood on the Riverbanks together," but now we find that there are all sorts of dividing lines 
that separate the people of the barricades into hierarchically arranged groups? If the tauta experienced itself as a revolutionary force in 1991, how did the same people come to see each other as members of different social and ethnic groups in the aftermath of the barricades while at the same time recognizing and lamenting their unity at the barricades?

We argue here that the sense of betrayal is not only-or not necessarilyattributable to the failings of the people, as suggested by the Pride participant who noted that Latvian society is "far from truly understanding democracy." Rather, it is also produced by modern practices of governing requiring that populations be categorized and divided in order to be governed, giving rise to an identity politics that conceives of political struggle as a struggle between historically differentiated majority and minority groups (Brown 1995; Foucault 1988; 2003). In moments when such divisions become especially pronounced, as was the case during the 2006 and 2007 Pride parades, the barricade sociality of 1991 emerges as a critique of modern practices of governing and the associated politics. Whether instantiated through making and maintaining barricades, or by remembering such practices, barricade sociality in Latvia and Mexico questions governing by division and provides, if temporarily, a sense of alternative possibilities.

\section{MODERN POLITICAL ENTANGLEMENTS}

In this paper, we have traced the constitution of the revolutionary subject of the tauta and el pueblo through practices of barricade building in Latvia in 1991 and in Mexico in 2006. We have argued that the revolutionary potential conjured up by the people of the barricades questioned, if momentarily, hegemonic practices of governing associated with the modern nation-state. In doing so, however, we have sought to avoid romanticizing the tauta or el pueblo as purely transformative forces outside the hegemonic political terrain. Whether in Latvia or Oaxaca, the barricade sociality and ensuing collective subject position of the people were always-already shaped by and entangled with modern political imaginaries. To put it another way, the power of barricade sociality to articulate together a collective subject entailed a critique of modern practices of governing and a modern political imaginary that divides populations into the ethnic, social, and otherwise marked groups in the name of which politics are conducted. But at the same time, the political potential of barricade sociality - that is, its revolutionary vibration - was part and parcel of a normative socio-political order and discursive formation where the modern nation-state was understood as the hegemonic means of organizing collective life.

In order to trace these entanglements, and as a way to conclude, we return to the discussion of the state with which we began the paper. As Louis Althusser (1970), Antonio Gramsci (1971), Timothy Mitchell (1991), Michel Foucault (1994), and others have argued, the state is not merely synonymous with or circumscribed by government institutions. Rather, whether through 


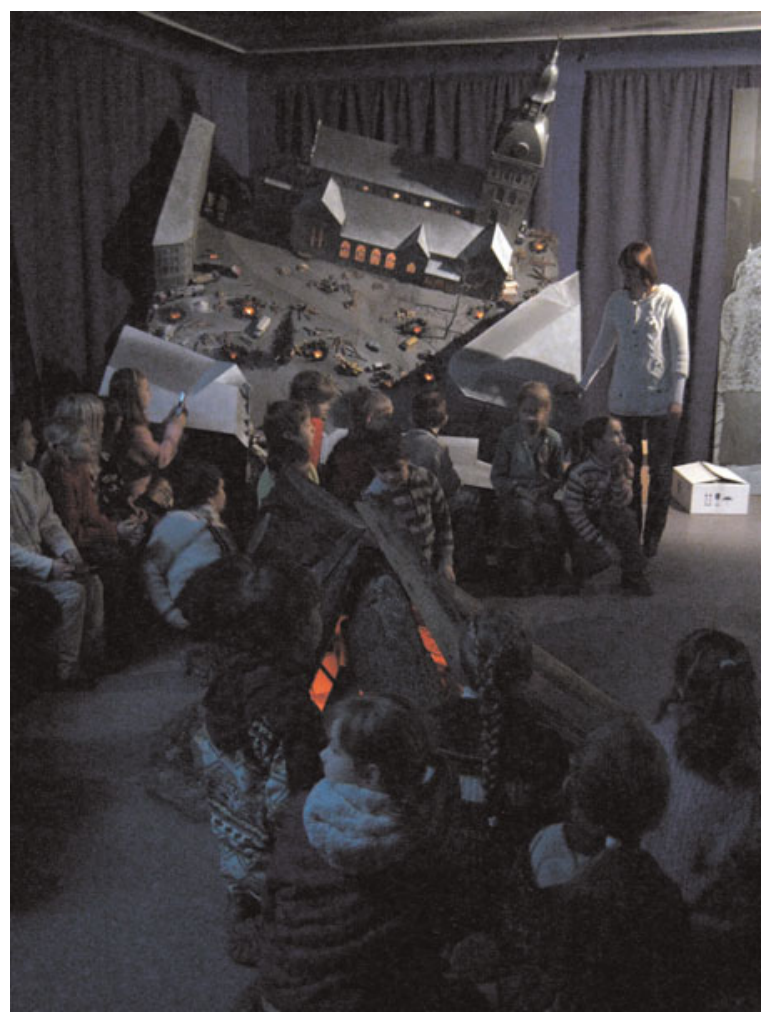

FiguRE 10 A group of schoolchildren visiting the Museum of the Barricades in Riga, 2009. Photo by Dace Dzenovska.

Ideological State Apparatuses, hegemony, or governmentality, the state is constituted through practices that create what Mitchell (1991) has called the "state effect." The state, therefore, does not reside in concrete institutions and bureaucratic structures, but rather is conjured up through particular ways of thinking about and conducting public and political life - ways of thought and conduct that are not outside of, but in fact inform insurgent, revolutionary action.

In his analysis of modern public and political life, Michael Warner argues that modern publics are imagined as formations that come into being through the circulation of rational discourse in the public arena and thus hail individuals as members of publics (2005: 65-124). Warner uses the term "state-based thinking" to mark how modern publics imagine their political force and collective agency in relation to the state and argues that, as a result, embodied forms of sociality are excluded as illegitimate public presences (ibid.: 124). Thus, in Warner's argument, "state-based thinking" not only pertains to political action that appeals 
to state institutions, but also to thought and conduct that corresponds to certain normative criteria, such as rational discourse. The notion of "state-based thinking" helps us to point out how barricade sociality in Oaxaca and Latvia both transgressed state-based thinking and was entangled with it.

In Oaxaca, for example, after the violent repression of the teachers' strike and general dissatisfaction with the democratic patriarchal governing practices of PRI functionaries led to the formation of APPO in mid-June of 2006, the general call to oust Governor Ulises Ruiz Ortiz was not paired with demands to dismantle the state. By the end of June, though, participation in practices of protest that included taking over the zócalo, holding local and state assemblies to make decisions, and mega-marches through city streets led to radically different imaginations of Oaxaca's public and political life. Thus, on 28 June, after the fourth APPO mega-march gathered between five hundred thousand and one million people in a nine-mile march from Oaxaca's airport to the city sports stadium to hold a state-wide assembly, journalist Nancy Davies reported, "The talk is of constitutional changes.... The present coalition ... hopes assemblies will replace the elected legislature controlled by the PRI" (2007: 33). From a teachers' movement looking for better working conditions to APPO pushing for constitutional changes and rule by general assemblies less than a month later, practices of protest engendered a barricade sociality whose embodied and discursive formation was giving shape to radically different imaginations about Oaxaca's social and political future. Entangled with, yet reworking Mexico's democratic patriarchy, barricade sociality in Oaxaca enabled concrete practices of self-organization that not only conjured up el pueblo as a revolutionary force, but also as a collective subject that can govern itself rather than one in whose name the state governs.

The continuing practice of holding neighborhood assemblies and of placing images on the streets reminds all Oaxacans of one of the most important lessons of the APPO movement, namely that "history begins at ground level, with footsteps" (de Certeau 1984: 129). Whether expressed through participation in political marches that take over city streets, in appropriating city walls to display political imagery, or by the building of neighborhood parks on unused lands by communities weary of government promises, activists, artists, and ordinary Oaxacans are forming alternative conceptions and practices of ethical communities that bypass state-based and neoliberal frameworks as the necessary horizon of Oaxaca's future. As Esteva points out, "In the face of the failure of democratic apparatuses ... communities have begun to appear as alternatives. They have become so, more than any other reason, because there does not seem to be any other option, but also because of the conviction that the future will be, in one way or another, a communal act" (2007: 29). Neighborhood and community projects today are often undertaken by new groups that formed during the 2006 movement and by communities who identify themselves as part of el pueblo. Unlike the focus on community deployed by 
neoliberal institutions via the language of self-help and empowerment (Mohan and Stokke 2000), however, in Oaxaca organized communities and groups often voice an explicit desire not only to bypass or excise all local, state, or national government connections from their lives, but also to "cleanse their view" (limpiar la mirada) from state-based thinking. While they understand that complete separation from "the system" is not possible, many groups have expressed a clear frustration at the inadequacies and inefficiencies of representative democracy to address their needs, and they remain mobilized and looking for alternative political practices. Indeed, with voting absenteeism as high as 70 percent in a 2007 municipal election, Oaxaca's struggle is producing new definitions of political agency and responsibility as it redefines what it is to be a part of an emerging collective along the lines of an activist citizenrya form of community publicness often rendered as convivialidad (conviviality).

In Latvia, while barricade sociality shaped the tauta as a "cosmic force" uniting ethnically, sexually, and politically defined publics and groups and thus disrupted the governing practices of the state that divide the population along majority and minority lines, the state remained integral to the political imaginaries of collective life after the barricades. Today, imaginations of the constitution of a proper democratic nation-state continue to animate the political practices of gay and lesbian activists and of the former people of the barricades, despite the way in which recollections of barricade sociality from 1991 offer a critique of the majority/minority confrontations that resulted from Pride parades. Ultimately, the fences that separated minority Pride participants from their majority opponents were less sturdy than the barricades, but they gained force and power via their articulation with the state in the form of the professional police force that patrolled them, as well as via the state's legal machinery that regulated (or denied) parade routes. The leap from the barricades to the mesh fence enclosures quickly compresses time and brings into sharp focus the state-building that has occurred in the years between the two events. With people on both sides of the fence making claims against the state to fulfill its duties, the articulation of the tauta with a nation-state that adhered to liberal democratic principles produced a tension between majority rule and minority rights. While regretting that they had to assemble within an enclosure, gay and lesbian activists expressed pride and satisfaction that in 2007 the state had fulfilled its commitment to minority protection, contrary to 2006 when it failed to do so by refusing police protection to Pride participants. While holding a Pride parade despite political and public opposition might be seen as a practice of taking rights rather than asking for them from sovereign power (Honig 2003), ${ }^{22}$ the organization of Pride parades also relied on the

${ }^{22}$ In Democracy and the Foreigner, Bonnie Honig uses the figure of the immigrant to develop a vision of democracy as an active subjectivity: "Not all takings are performed by immigrants or foreigners, but they are all performed by subjects who are not fully included in the system of 
state by applying for permits, demanding state protection, and aiming to educate public officials about the constitutional rights of a minority group. Similarly, Pride opponents appealed to the state's responsibility towards the majority not only as a democratic people but also as a moral community. The politics of Pride were not only structured through these entanglements with state institutions, but also by particular understandings of society as a formation consisting of differentiated social groups whose relations to each other the state needed to mediate.

Arguments over gay and lesbian visibility and politics thus emerged as platforms for arguments about diverging understandings of democracy, the relationship between the majority, a minority, and the state, as well as about the relationship of all three with European human rights discourses. Gay and lesbian activists often lamented that Latvian society is not yet sufficiently democratic, while assuring themselves and others that it will eventually "catch up" with the world's liberal democracies. Measured by these standards, although Latvia has some distance to go before becoming a proper democratic nation, it is well on its way. There seems to be little if any uncertainty for gay and lesbian activists about the necessary path of liberalization and democratization. While it is fairly easy to ally with activists against violent protesters, the story becomes more complicated if one considers how the widespread opposition to Pride parades and gay and lesbian politics - one that goes beyond abusive protests and is more mainstream - may also be a critique of specific conceptions of the relationship between sexual practice, identity, and particular political forms and subjectivities (Brown 1995; Warner 1999). In other words, it is far from clear that the public and political life advocated by Latvian gay and lesbian activists via public Pride parades is the only imaginable or legitimate mode of modern gay or lesbian existence. ${ }^{23}$

While political struggles around LGBT rights have their own specific history in Latvia that differs from other political struggles, such as those surrounding ethnic minorities, they nevertheless inhabit a shared discursive formation where political claims are made vis-à-vis the state. In Oaxaca, the entangled relationship between the political struggles of el pueblo and the state has a different history, one that affects not only the terrain of struggle, but also the political imagination of who people are struggling against and for what aim. Images from 2008 inviting public reflection on gay and lesbian life in Oaxaca and Latvia offer an excellent illustration of the differently

rights and privileges in which they live. The practice of taking rights and privileges rather than waiting for them to be granted by a sovereign power is ... a quintessentially democratic practice" (2003: 99; see also Lefebvre 2000 and his concept of "rights to the city.")

23 Much has been written on the internationalization of gay and lesbian politics in non-Western contexts, including critiques of normative LGBT politics in both the West and the non-West (Donham 1998; Massad 2007; Warner 1999). 
oriented political imaginaries in each place. While Pride posters in Latvia depicted the bucolic family life of both heterosexual and homosexual couples alongside each other, in Oaxaca, a woman stenciled on the wall stares directly at passersby and, after affirming she is a lesbian, asks why they are heterosexual.

While it is beyond the scope of this paper to fully elaborate on the normative aspects of gay and lesbian politics in Latvia (see Dzenovska 2009), we do want to point out how positing a Western middle class notion of gay and lesbian identity and politics as an indicator of democracy, and resistance to it as backward nationalism, constitutes political state-based liberalism as the only progressive political horizon. This overlooks other ways of being and doing politics, as well as other ways of practicing homosexuality. Both are worthy of critical consideration, for in Latvia there were considerable differences in how various homosexually oriented persons conceived of their sexual practice in relation to their public and political persona. Similarly, there were heated debates in online gay and lesbian networks about Pride as a political form. Whereas gay and lesbian activists emphasized the importance of "coming out" and being public about one's sexual identity, many of Latvia's "gays" and "lesbians" doubted whether homosexual practices were necessarily linked with identity or whether leading a gay or lesbian life required public visibility. Many questioned Pride as a political form, instead suggesting collaborative (rather than confrontational) and less public political strategies. To be sure, many in Latvia support the activities of gay and lesbian activists and membership in the LGBT organization has grown, but the significant differences of opinion and practice within gay and lesbian networks in Latvia help to bring into focus the state-based and normative nature of gay and lesbian politics proposed by the organizers of the Pride.

In conclusion, we suggest that one of the central insights that a contemporary reflection on Oaxaca and Latvian barricades offers is to point out ways in which imaginations of political horizons and practices articulated with democracy produce reductive readings of politics and political transformations whereby the idea of revolution remains that of "a political change at the level of the state" (Lefebvre 1995: 422). Much mainstream political activism remains mesmerized by the mirage of state power and continues to be spellbound by the allure of discourses of democracy promising power to the people. Rather than assess social movements in the Global South instrumentally through the filters of discourses of democratic representation or human rights, through our focus on barricade sociality we are arguing for attention to how practices of protest - such as the raising of barricades in Egypt produce transformative social formations in their own right, even if these are not always successful in toppling regimes or in achieving model democracies. The concept of barricade sociality asks us to reconsider the kinds of questions and political perspective through which the Egyptian revolution and the Arab 
674 DACE DZENOVSKA AND IVÁN ARENAS

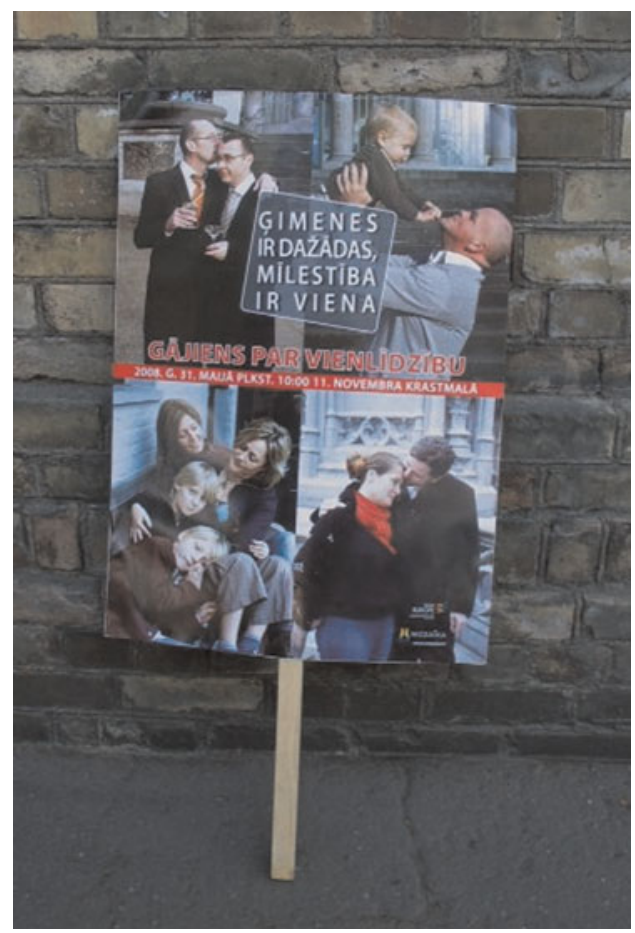

Figure 11 A 2008 Pride Poster in Riga. Photo by Dace Dzenovska.

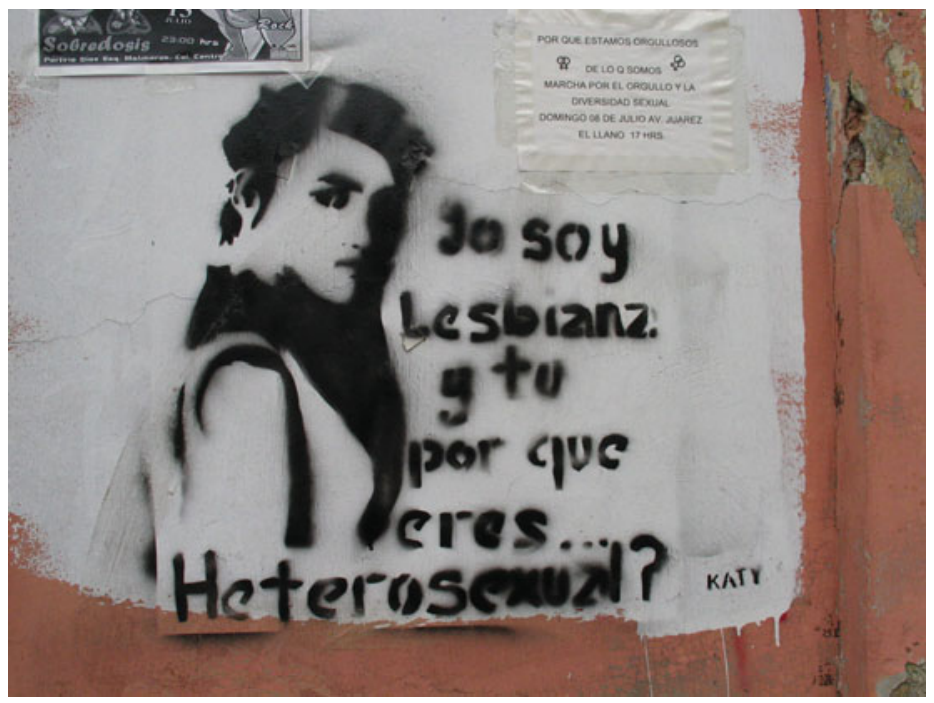

Figure 12 A 2008 stencil in Oaxaca. Photo by Iván Arenas. 
Spring are assessed; by focusing more closely to the generative power of the practices of protest, we may be able to see what kind of political formations are being debated, imagined, and practiced without letting them be drowned out by the horns of freedom and democracy.

\section{REFERENCES}

de Aguinaga, Fernando Gálvez. 2007. Ulises, el mago que desapareció los poderes. In Carlos Beas Torres, ed., La batalla por Oaxaca. Oaxaca, Mexico: Yope Power, 117-20.

Althusser, Louis. 1970. Ideology and Ideological State Apparatuses (Notes Towards an Investigation). In Lenin and Philosophy and other Essays. Ben Brewster, trans. New York: Monthly Review Press, 127-86.

Arellanes Meixueiro, Anselmo. 2007. Zócalo destruido, pueblo enfurecido. Cuadernos del Sur 12, 24/25: 139-48.

Arenas, Iván. 2011. Rearticulating the Social: Spatial Practices, Collective Subjects, and Oaxaca's Art of Protest. PhD diss., University of California, Berkeley.

Arenas, Iván and Dace Dzenovska. 2010. Making 'the People': Political Imaginaries and the Materiality of Barricades in Mexico and Latvia. In Mariana Heredia and Olessia Kirtchik, eds., "Former USSR and Latin America: Studies in Post-Authoritarian Transformations." Laboratorium: The Russian Social Sciences Review 2 (special issue): 179-99.

Arendt, Hanna. 1968. On Revolution. New York: The Viking Press.

Arendt, Hanna. 1979. The Origins of Totalitarianism. New York: Harvest/HBJ.

Bicēna, Baiba. 2010. Barikāžu laiks: apvērsums. 1991. Gada pieraksti. Riga: Zvaigzne $\mathrm{ABC}$.

Brown, Wendy. 1995. States of Injury. Princeton: Princeton University Press.

Buchli, Victor, ed. 2002. The Material Culture Reader. New York: Berg.

Buck-Morss, Susan. 2000. Dreamworld and Catastrophe: The Passing of Mass Utopia in East and West. Cambridge, Mass.: MIT Press.

de Certeau, Michel. 1984. The Practice of Everyday Life. Steven Rendall, trans. Berkeley: University of California Press.

Cowan, Jane. 2007. The Supervised State. Identities 14, 5: 545-78.

Daugmalis, Viktors, ed. 2001a. Barikādes: Latvijas mīlestības grāmata. Riga: Barikāžu atbalsta fonds.

Daugmalis, Viktors. 2001b. Barikādes. Riga: Barikāžu atbalsta fonds.

Davies, Nancy. 2007. The People Decide: Oaxaca's Popular Assembly. New York: Narco News Books.

Diakonie and the International Commission of Jurists. 2007. Informe de la visita de la Comisión Internacional de Juristas y la obra Diacónica Alemana a Oaxaca, México. At: http://www.serapaz.org.mx/paginas/Informe\%20Oaxaca\%20Noviembre\%202007. pdf (accessed 15 Mar. 2012).

Donham, Donald. 1998. Freeing South Africa: The 'Modernization' of Male-Male Sexuality in Soweto. Cultural Anthropology 13, 1: 3-21.

Doumani, Beshara. 2011. Arab Uprisings and Middle East Studies: Roundtable with Beshara Doumani, Charles Hirschkind, Saba Mahmood, and Stefanial Pandolfo. Jadaliyya, 17 May. At: http://www.jadaliyya.com/pages/index/1607/arab-uprisingsand-middle-east-studies roundtable- (accessed 15 Mar. 2012).

Dribins, Leo. 1997. Nacionālais jautājums Latvijā, 1850-1940: historiogrāfisks apskats. Riga: Mācību apgāds. 
Dzenovska, Dace. 2009. Provoking Tolerance: History, Sense of Self, and Difference in Latvia. PhD diss., University of California, Berkeley.

Dzenovska, Dace. n.d. How to Be a Minority: The Politics of Conduct and Difference in the New Europe. MS in preparation.

Eiss, Paul K. 2008. El Pueblo Mestizo: Modernity, Tradition, and Statecraft in Yucatán, 1870-1907. Ethnohistory 55, 4: 525-52.

Esteva, Gustavo. 2007. La otra campaña, la APPO y la izquierda: reivindicar una alternativa. Cuadernos del Sur 12, 24/25 (Nov.): 7-37.

Esteva, Gustavo. 2008. Crónica de un movimiento anunciado. In Cuando hasta las piedras se levantan. Oaxaca, México, 2006. Buenos Aires: Editorial Antropofagia, 21-89. Also at: http://www.ger-gemsal.org.ar/files/pdf/libros/cuandohastalaspiedras. pdf (accessed 15 Mar. 2012).

Foucault, Michel. 1988. The Subject and Power. In Hubert F. Dreyfus and Paul Rabinow, eds., Michel Foucault: Beyond Structuralism and Hermeneutics. Chicago: University of Chicago Press, 208-26.

Foucault, Michel. 1994. On Governmentality. In James D. Faubion, ed., The Essential Works of Foucault, Volume 3 (Power). New York: The New Press, 201-22.

Foucault, Michel. 2003. Society Must Be Defended. David Macey, trans. New York: Picador.

Gamio, Manuel. 2010 [1916]. Forjando Patria: Pro-nacionalismo. Boulder: University Press of Colorado.

Gay, José Antonio. 2006 [1881]. História de Oaxaca. Oaxaca: Editorial Porrua.

Gijsbers, Wim. 2007. David Venegas: la barricada y la resistencia social. In Carlos Beas Torres, ed., La batalla por Oaxaca. Oaxaca: Yope Power, 243-48.

Gobinšs, Mārcis. 2006. Geju praida aizliegums Satversmes 110. panta gaismā. politika.lv, 31 July. At: http://archive.politika.lv/temas/cilvektiesibas/20534/ (accessed 15 Aug. 2010).

Gramsci, Antonio. 1971. Selections from the Prison Notebooks. Quintin Hoare and Geoffrey Nowell Smith, eds. and trans. New York: International Publishers.

Hacking, Ian. 2007. Kinds of People, Moving Targets. British Academy Lecture delivered on 11 Apr. At: www.proc.britac.ac.uk/tfiles/151p285.pdf (accessed 15 June, but at time of the present publication the link no longer worked).

Harvey, David. 1973. Social Justice and the City. Athens: University of Georgia Press.

Hirschkind, Charles. 2011a. Uprising in Egypt: The Road to Tahrir. In Jonathan VanAntwerpen, ed., The Immanent Frame: Secularism, Religion, and the Public Sphere. Social Science Research Council. At: http://blogs.ssrc.org/tif/2011/02/09/ the-road-to-tahrir/ (accessed 15 Mar. 2012).

Hirschkind, Charles. 2011b. How Do We Define U.S. Interests in Egypt? San Francisco Chronicle, 8 Feb. At: http://www.sfgate.com/cgi-bin/article.cgi?f=/c/a/2011/02/08/ EDCI1HJVFB.DTL (accessed 15 Mar. 2012).

Honig, Bonnie. 2003. Democracy and the Foreigner. Princeton: Princeton University Press.

Kazans, Jānis. 2008. Ko glabā to dienu atminas? At: www.liepajniekiem.lv/lat/zinas/ aktuali/2008/01/17/pagtne-ietamba-stenba/ (accessed 5 Sept. 2009).

Kourí, Emilio H. 2002. Interpreting the Expropriation of Indian Pueblo Lands in Porfirian Mexico: The Unexamined Legacies of Andrés Molina Enríquez. Hispanic American Historical Review 82, 1: 69-117.

Laclau, Ernesto. 2007. On Populist Reason. New York: Verso.

Laclau, Ernesto and Chantal Mouffe. 1985. Hegemony and Socialist Strategy: Towards a Radical Democratic Politics. New York: Verso. 
Lefebvre, Henri. 1995 [1974]. The Production of Space. Donald Nicholson-Smith, trans. Cambridge, Mass.: Blackwell Publishers.

Lefebvre, Henri. 2000 [1968]. Writings on Cities. Eleonore Kofman and Elizabeth Lebas, eds. and trans. Malden, Mass.: Blackwell Publishers.

Lepinay, Vincent-Antonin. 2007. Economy of the Germ: Capital, Accumulation, and Vibration. Economy and Society 36, 4: 526-48.

Lomnitz, Claudio. 2001. Deep Mexico, Silent Mexico: An Anthropology of Nationalism. Minneapolis: University of Minnesota Press.

Mahmood, Saba. 2005. Politics of Piety: The Islamic Revival and the Feminist Subject. Princeton: Princeton University Press.

Mallon, Florencia E. 1995. Peasant and Nation: The Making of Postcolonial Mexico and Peru. Berkeley: University of California Press.

Martínez Vásquez, Víctor Raúl. 2007. Autoritarismo, Movimiento Popular y Crisis Politica: Oaxaca 2006. Oaxaca: Carteles Editores-P.G.O.

Marx, Karl. 1990 [1867]. Karl Marx: Selected Writings. David McLellan, ed. New York: Oxford University Press.

Massad, Joseph. 2007. Desiring Arabs. Chicago: University of Chicago Press.

Miller, Daniel, ed. 2005. Materiality. Durham: Duke University Press.

Mitchell, Don. 2003. The Right to the City: Social Justice and the Fight for Public Space. New York: The Guilford Press.

Mitchell, Timothy. 1991. The Limits of the State: Beyond Statist Approaches and Their Critics. American Political Science Review 85, 1: 77-96.

Mohan, Giles and Kritian Stokke. 2000. Participatory Development and Empowerment: The Dangers of Localism. Third World Quarterly 21, 2: 247-68.

Nagle, Ilze. 2007. Naids kā sāpīgs bumerangs. Sestdiena, 2 July. At: www.diena.lv/ arhivs/naids-ka-sapigs-bumerangs-13152138 (accessed 16 Mar. 2012).

Poole, Deborah. 2004. An Image of 'Our Indian': Type Photographs and Racial Sentiments in Oaxaca 1920-1940. Hispanic American Historical Review 84, 1: 37-82.

Purs, Aldis. 2002. The Price of Free Lunches: Making the Interwar Latvia in the Frontier. Global Review of Ethnopolitics 1, 4: 60-73.

Rancière, Jacques. 2004. The Politics of Aesthetics: The Distribution of the Sensible. Gabriel Rockhill trans. New York: Continuum.

Schneider, Nathan. 2011. The Suspicious Revolution: An Interview with Talal Asad. In Jonathan VanAntwerpen, ed., The Immanent Frame: Secularism, Religion, and the Public Sphere. Social Science Research Council. At: http://blogs.ssrc.org/tif/2011/ 08/03/the-suspicious-revolution-int (accessed 10 Aug. 2011).

Silova, Iveta. 2006. From the Sites of Occupation to Symbols of Multiculturalism: Reconceptualizing Minority Education in Post-Soviet Latvia. Greenwich: Information Age Publishing.

Slezkine, Yuri. 1994. The USSR as a Communal Apartment, or How a Socialist State Promoted Ethnic Particularism. Slavic Review 53, 2: 414-52.

Soja, Edward W. 2010. Seeking Spatial Justice. Minneapolis: University of Minnesota Press.

Spivak, Gayatri Chakravorty. 1988. Can the Subaltern Speak? In C. Nelson and L. Grossberg, eds., Marxism and the Interpretation of Culture. Urbana: University of Illinois Press, 271-313.

Stukuls Eglitis, Daina. 2002. Imagining the Nation: History, Modernity and Revolution in Latvia. University Park: Pennsylvania State University Press.

Taylor, Charles. 2007. Modern Social Imaginaries. Durham: Duke University Press.

Traugott, Marc. 2010. The Insurgent Barricade. Berkeley: University of California Press. 
Vasconcelos, José. 1997 [1925]. The Cosmic Race/La raza cósmica. Baltimore: Johns Hopkins University Press.

Warner, Michael. 1999. The Trouble with Normal: Sex, Politics, and the Ethics of Queer Life. Cambridge, Mass.: Harvard University Press.

Warner, Michael. 2005. Publics and Counterpublics. New York: Zone Books.

Watts, Michael. 2004. Antinomies of Community: Some Thoughts on Geography, Resources and Empire. Transactions of the Institute of British Geographers (New Series) 29, 2: 195-216.

Weitz, Eric D. 2008. From the Vienna to the Paris System: International Politics and the Entangled Histories of Human Rights, Forced Deportations, and Civilizing Missions. American Historical Review (Dec.): 1313-43.

Wright, Jonathan. 2011. Tahrir Square behind the Barricades. At: http://jnthnwrght.blogspot.com/2011/02/tahrir-square-behind-barricades.html (accessed 15 Mar. 2012).

Younis, Jumanah. 2011. Egypt's Revolution Means Nothing if It's Women Are not Free. Guardian, 9 Mar. At: http:/www.guardian.co.uk/commentisfree/2011/mar/09/ egypt-revolution-women?INTCMP=SRCH (accessed 15 Mar. 2012).

Žižek, Slavoj. 2001. How Did Marx Invent the Symptom? In The Sublime Object of Ideology. New York: Verso, 11-54.

Abstract: In 1991, barricades in the streets of Riga, Latvia, shielded important landmarks from Soviet military units looking to prevent the dissolution of the USSR; in 2006, barricades in the streets of Oaxaca, Mexico, defended members of the Popular Assembly of the Peoples of Oaxaca from paramilitary incursions. We employ these two cases to compare the historically specific public socialities and politics formed through spatial and material practices in moments of crisis and in their aftermath. We show how the barricades continue to animate social and political formations and imaginaries, providing a sense of both past solidarity and future possibilities against which the present, including the state of the polity and the life of the people, are assessed. We trace the convergences and differences of political imaginaries of barricade sociality that formed in the barricades' aftermath and consider what their transformative potential might be. Attentive to the specificity of particular practices and social relations that produce a collective subject, we consider how our case studies might inform broader questions about social collectives like the nation and publics. Though they point in different directions, we argue that the barricades provide an enabling position from which to imagine and organize collective life otherwise. In a moment when much mainstream political activism remains spellbound by the allure of discourses of democracy that promise power to the people, the Mexico and Latvia cases provide examples of social life that exceeded both state-based notions of collectives and what Michael Warner has called "state-based thinking," even as they were also entangled with state-based frames. 